\title{
ECONOMIC IMPERATIVES AND ETHICAL VALUES IN GLOBAL BUSINESS
}

The South African Experience and International Codes Today 


\section{ECONOMIC IMPERATIVES \\ AND ETHICAL VALUES \\ IN GLOBAL BUSINESS}

\section{The South African Experience and International Codes Today}

by

S. Prakash Sethi

Baruch College

and

Oliver F. Williams

University of Notre Dame

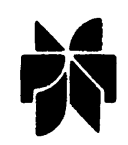

SPRINGER SCIENCE+BUSINESS MEDIA, LLC 


\section{Library of Congress Cataloging-in-Publication Data}

\section{Sethi, S. Prakash.}

Economic imperatives and ethical values in global business : the South African experience and international codes today / S. Prakash Sethi and Oliver F. Williams.

p. $\mathrm{cm}$.

Includes bibliographical references and index.

$$
\text { ISBN 978-1-4613-7024-6 ISBN 978-1-4615-4491-3 (eBook) }
$$

DOI 10.1007/978-1-4615-4491-3

1. Business ethics--South Africa. 2. Economics--Moral and ethical aspects-South Africa. 3. Corporations, Foreign--South Africa. 4. Anti-apartheid movements--South Africa. 5. South Africa-Social conditions. I. Williams, Oliver F. II. Title.

HF5387.5.S6 S485 2000

174'.4--dc21

00-055993

Copyright C 2000 by Springer Science+Business Media New York

Originally published by Kluwer Academic Publishers in 2000

Softcover reprint of the hardcover 1st edition 2000

All rights reserved. No part of this publication may be reproduced, stored in a retrieval system or transmitted in any form or by any means, mechanical, photocopying, recording, or otherwise, without the prior written permission of the publisher, Springer Science+Business Media, LLC.

Printed on acid-free paper. 
To Reverend Leon H. Sullivan

A Person of Uncommon Wisdom and Generosity 


\section{Contents}

List of Acronyms $\quad$ ix

Foreword by Rev. Leon Sullivan $\quad$ xi

Preface $x v$

Part I. The Setting

1 A Multinational Code of Conduct for South Africa 3

2 The Emergence of the Anti-Apartheid Movement 27

3 The First Step toward Implementation 57

4 Shaping the Organization $\quad 81$

5 Measuring Progress $\quad 99$

Part II. The Sullivan Principles in Action

6 Eli Lilly \& Company, Inc. 127

7 Ford Motor Corporation of South Africa 139

8 Raising the Ante 159 
9 European and Other Codes of Conduct for the Companies Operating in South Africa

10 Corporate Compliance with the Sullivan Principles

Part III. Conflicting Forces

11 The Comprehensive Anti-Apartheid Act of 1986

12 The Anti-Apartheid Movement and Its Impact on United States Companies to Withdraw from South Africa

Part IV. The End Game

13 Stampeding toward the Exit

14 Repeal of the Comprehensive Anti-Apartheid Act of 1986

15 The Rocky Road to Post-Apartheid South Africa

\section{Part V. Epilogue}

16 Assessment of the Sullivan Principles As a Role Model for Developing International Codes of Conduct

About the Authors

Bibliography

Index 


\section{List of Acronyms}

ACOA American Committee on Africa

$\mathrm{AHI}$

Afrikaanse Handelsinstituut (Africaans Chamber of Commerce)

AMCHAM American Chamber of Commerce in South Africa

ANC African National Congress

ARMSCOR Armaments Development Corporation of South Africa ASSOCOM Associated Chamber of Commerce in South Africa

AZAPO

BCA Azania People's Organization

CAAA

CCSA

Black, Colored, and Asian

Comprehensive Anti-Apartheid Act of 1986.

Christian Council of South Africa (the precursor to the SACC)

CODESA Congress for Democratic South Africa

CORE

COSATU

Congress of Racial Equality

DRC

Congress of South African Trade Unions

Dutch Reformed Church (usually used in reference to the NGK)

EPG Eminent Persons Group, of the Commonwealth Countries

ICCR Interfaith Center on Corporate Responsibility

IMF International Monetary Fund

IRRC Investor Responsibility Research Center

ISU Industry Support Unit (of the Sullivan Principles)

MK Shorthand for Umkhonto We Sizwe (Spear of the Nation)

NAACP National Association for the Advancement of Colored People

NAFCOC National African Federated Chamber of Commerce 
NGK Nederduits Gereformeerde Kerk (Dutch Reformed Church)

NUM National Union of Mineworkers

$\mathrm{OAU} \quad$ Organization of African Unity

PAC Pan Africanist Congress

SACBC Southern African Catholic Bishops' Conference, Pretoria

SACC South African Council of Churches, Johannesburg

SACTU South African Congress of Trade Unions

SASA South African Signatory Association (of the Sullivan

Principles)

UDF United Democratic Front

WARC World Alliance of Reformed Churches

WCC World Council of Churches 


\section{Foreword by Rev. Leon Sullivan}

The authors of this book pay me a great compliment in that they credit my work with the Sullivan Principles in South Africa as the stimulus for a major change in the way business today views its role in society. I will let the reader be the judge of that, but I can say that this volume brings together an excellent, comprehensive account of what I was trying to do with the Principles and of the many battles that had to be won for their success. Perhaps no other two scholars in the world have had more "hands on" experience with the anti-apartheid movement and the related economic and political issues in South Africa. During the 15+ long years of struggle, they were not only on the ground observing and analyzing the situation, but also becoming involved in improving the implementation of the Principles. By cajoling the corporations and nongovernmental organizations-both secular and religious - they were able to enhance the cause of the Sullivan Principles. It was because of the trust and esteem in which they were held by all concerned that their advice and counsel was sought and listened to by all sides. Working with thousands of documents and letters in the archives, and with personal, on-the-record interviews with a large number of significant players, they have created a unique combination of a scholarly and first-hand account of events. This research is backed by exhaustive data analysis, with the result that we have a highly objective, empirically based, and yet personal perspective of this grand experiment. Through lucid and incisive writing, they have recreated the tensions and the tenor of the times from the mid-seventies until the dismantling of statutory apartheid in April 1994 with the first democratic election.

My basic position in 1975, when I first raised the apartheid issue with United States business leaders, was that we couldn't check our moral and 
religious values at the office door. Apartheid was an evil, and business had great power in South Africa. Where there is power, there is also responsibility. I prayed about this long and hard. I pushed the companies as much as I thought I could. There were advances and there were setbacks, but finally we prevailed and the Blacks of South Africa secured their freedom. My effort in behalf of the Sullivan Principles was only one of a number of significant efforts of the anti-apartheid movement. All of those other efforts must be recognized, as well.

The Sullivan Principles and the manner in which they were implemented in South Africa were in the nature of a grand experiment in the sociopolitical change and economic uplifting of the Black people of South Africa. What is even more important is that the Principles were driven by an ethical and moral imperative, and were voluntarily implemented by a group of enlightened United States multinational corporations. No grand design or vision is ever perfect. We fall prey to human follies, limited understanding of the future, and necessary compromises to seek not what is perfect but what is possible. Thus, any such effort is subject to criticism from those who seek ideological purity and those who seek to minimize the impact of change from the status quo.

One point the authors do capture well is that my guiding vision was then-and remains today-that overcoming political apartheid is not enough. The dual focus of overcoming political and economic apartheid has been my life's work. My experience in the United States civil rights movement taught me that mobilizing the resources to teach disadvantaged Blacks important job skills was just as important as working for political rights. I preached to business that they had the power to right some of these wrongs, and some businesses responded with generous and careful programs. It is those businesses that have my highest admiration and blessings. Others who continue to focus single-mindedly on making money will, no doubt, find that new champions for the poor and dispossessed will rise to the occasion. As the authors suggest, there is a new paradigm for the role of business and society.

I would leave it to the capabilities of these two scholars to interpret the workings of the Principles, and to the readers to assess the validity of their assertions and interpretations. One thing, however, is certain. The working of the Sullivan Principles in South Africa offers invaluable lessons that are increasingly relevant in today's highly contentious global business environment, especially with respect to human rights, individual freedom, sweatshop working conditions, a living wage, social equity, moral fairness, and protection of the environment. They offer practical lessons from the one and only full-scale experiment in crafting a code of conduct, ensuring its implementation, and creating mechanisms for independent monitoring, verifica- 
tion of results, and public dissemination of findings. As such, this book should be required reading for all those who must contend with such problems in the global context. A failure to attend to the book's lessons would condemn us to repeat our mistakes. This would be a tragedy of monumental proportions: it would inflict unnecessary economic costs on all the parties involved, be the cause of avoidable human pain and suffering, and exacerbate political instability and social unrest in the countries involved.

Leon H. Sullivan

Phoenix, Arizona 


\section{Preface}

Nowhere in the annals of the history of international business, and especially the history of multinational corporations (MNCs), has there been an experiment so unique, and yet so profound, as the operations of the United States companies in South Africa under the White-dominated regime that practiced legalized apartheid. The experiment started modestly when a small group of major United States-based MNCs, inspired by a Black clergyman, agreed to abide by a set of six principles that called for, among other things, the elimination of all types of discrimination between White and Black workers; the recognition of Black unions; and providing help for the Black communities in the areas of education, health care, and other social-support activities.

The six principles that came to be known as the Sullivan Principles-named after their originator, Rev. Leon H. Sullivan-would become synonymous with the ascendance of moral principles over purely economic interests, with the power and influence of religious groups and social activists to change corporate behavior, and with the capacity of multinational corporations, however reluctantly, to bring about social and political changes in the host countries of their overseas operations. From its modest beginnings, the Sullivan Principles pro-

gram mushroomed into one of major national and international importance, and became a lightning rod in accelerating the process of sociopolitical change in South Africa.

The Sullivan Principles constituted the first of the voluntary codes of ethical conduct that were applied under realistic operating conditions and that involved a large number of corporations, recipient constituencies, and an institutional framework for project implementation, monitoring, and performance evaluation. The Principles program had a large measure of moral authority to validate 
corporate actions and, where necessary, to exhort companies to undertake activities that they might otherwise consider ill advised. It also presented an excellent laboratory to examine the efficacy of various modes of corporate action undertaken in a hostile sociopolitical environment. It was a setting, moreover, in which the corporations' economic and social goals conflicted, and in which corporations' own South African managers did not fully support either the rationale for the Principles or the manner in which they were being applied to the subsidiaries in that country.

The operation of the Sullivan Principles during its eighteen years was not smooth, nor should it have been expected to be. The Principles program was unprecedented, undertaken in a tense and emotionally charged sociopolitical environment, and characterized by a large measure of mutual distrust between the corporations and their critics. Nevertheless, the Principles program served an extremely useful purpose both as a symbolic gesture indicating the moral repugnance of all civilized people against the evil of apartheid, and as a practical measure for providing sorely needed help to South Africa's poor and disenfranchised people.

Despite all the real or alleged weaknesses of the Principles program, no one with any knowledge either of multinational corporate codes of conduct or the developments in the field of corporate social responsibility could fail to recognize its crucial role in helping to legitimate such codes. Most corporations of any size now proudly display codes of conduct that outline, in varying degrees, their commitment to preserving the environment, offering fair wages and safe working conditions, and dealing equitably with customers and other stakeholders. Although a great deal of old rhetoric persists, and some of these codes have more to do with good public relations than substantive corporate actions, the fact remains that the legitimacy of these demands is now accepted by all sides. Debate has accordingly shifted to the content and implementation of these codes.

There is every indication to suggest that the business community, in general, and multinational corporations, in particular, will face increasing pressure to abide by codes of conduct in situations of perceived social wrongs - whether or not the corporations are the culprits or even directly involved, and whether or not they are in a position to bring about effective change. In an effort to inform such efforts, it would be a worthwhile objective to create an accurate and comprehensive record not only of the events surrounding the anti-apartheid movement in the United States and other parts of the world, but of the many ways in which that movement altered the economic and political landscape of South Africa. Such a record would demonstrate the immense complexity that characterizes all significant issues of public import. More importantly, the record would capture the very hazardous, unpredictable, and intense nature of the process through which important public issues are handled and resolved. It 
is a process that involves social institutions, and human beings-with all that is noble in them, and also with the ignoble cruelty that afflicts all of us. A study of that process would provide ample lessons for the corporate community, social activists, religious institutions, international organizations, and national governments about the effective strategies and tactics for dealing with similar issues.

This book, however, has a broader purpose. We intend to offer an analytical framework that will help us to understand business and society conflicts within a normative, economic, and contextual framework, and to evaluate the likelihood of success or failure of various strategic options and implementation formats that might be available for use in a given situation.

At the macrolevel, this book will look at:

- The sociopolitical environment that gives a particular issue of public policy its ideological-moral legitimacy, emotional intensity, and political potency; the role that different groups play in creating ownership of such an issue; and the process through which a supportive public-opinion environment is created.

- The linkages between domestic events and international events-linkages that are likely to enhance or weaken the saliency of a public policy issue-and the process through which these linkages are strengthened by advocacy groups.

- The linkages between moral/ethical values and economic considerations-linkages that define the operational characteristics of the social conflict, especially as to who does what to whom and with what effect, both on the conflict itself and on parties not otherwise involved in it.

- The manner and degree to which industry structure, competitive intensity, and companies' level of profitability influence these companies either to cooperate with various advocacy groups or to resist their demands.

- The different approaches that might be considered in developing codes of conduct. Should they be voluntary or mandatory in character? How should compliance be monitored and evaluated? Are there specific approaches that might be suitable for specific types of issues and external sociopolitical conditions?

At the microlevel this book will look at:

- What happens to parent-subsidiary economic relationships when the MNC's head office imposes certain moral/ethical operational rules on the local subsidiary. Available research on MNC parent-subsidiary relations suggests that there is strong tendency for the subsidiary's management to conceal information from the head-office staff when such information would adversely affect the operational autonomy of the local subsidiary even though the information might be beneficial for the MNC's home-country or global operations. 
- How adhering to parent MNC's social-policy goals might expose local managers to hostile peer-group reactions and create an adversarial relationship with local governmental agencies whose support is vital to the successful operations of the local subsidiary. The risk is that the aggressive pursuit of parent MNC's social goals might result in a weakening of the local subsidiary's competitive position.

- How the parent MNC might resolve the issues of performance measurement and evaluation, and of management compensation when the pursuit of social-policy goals potentially has an adverse impact on the subsidiary's economic performance. An alternative approach is determining how a company might develop monitoring and evaluation measures when performance on social-policy goals is considered an integral part of a subsidiary's overall performance.

- What measures companies can take to ensure that they are not held hostage, either by advocacy groups in their home country or recipient groups in the host country, to ever escalating standards of performance that disregard the company's vital strategic interests in its global operations.

- How MNCs resolve issues of internal conflict between managers and employees, and also between various groups of managers who may hold different views as to the desirability of adhering to parent MNC's social-policy goals; how such conflicts and the selected mode of conflict resolution affect the operations of the company; and how the potential for harm might be minimized.

The seeds of this book were planted in the authors' minds fifteen years ago, the product of our intensive involvement in the anti-apartheid debate in the United States and also of our participation in various activities and groups-both in United States and South Africa-engaged in the abolition of apartheid. In the process, we actively worked with, and listened to, a great many individuals and groups whose views and actions influenced and shaped our thoughts as to the salience and effectiveness of different approaches to voluntary social action, the importance of recognizing moral values as a necessary condition to economic action, and the possibilities and limitations of engaging large corporations to becone agents of positive social change.

This book became an active project almost five years ago when, following the democratic, nonracial elections, the people of South Africa took the destiny of that nation into their own hands, and the Sullivan Principles program was formally dissolved. In the course of writing the book, we benefited from the cooperation and support of a large number of people who willingly shared their views, challenged our opinions, and, in the process, helped us understand events, interpret data, and project our conclusions into future as to their relevance. It would be well-nigh impossible to mention each and every friend, colleague, and casual acquaintance who helped us at each step of our journey-from active participants in one of the most notable struggles 
for human freedom and dignity of the last quarter of the century, to scholarly interpreters of those events and what they might mean for the future of business-society relations. We are more than happy to share credit for this book with all those we expressly recognize and those whom we may have unwittingly omitted. Nevertheless, we reserve for ourselves the sole responsibility for any flaws in our reasoning and shortcomings in our conclusions.

Among the people who helped shape the course of events, both large and small, in South Africa and whom we were privileged to come to know and learn from are: Heribert Adam, Millard Arnold, Allan Boesak, Paul Buley, Mangosuthu G. Buthelezi, Aldredge B. Cooper, Herman Cohen, Chester Crocker, Msgr. Donald DeBeer, Zach DeBeer, Les de Villiers, Chris Dhlamini, Willie Esterhuyse, George Franklin, John Garbers, Wim R. Gevers, April Glaspie, Bobby Godsell, Richard Goldstone, Rudolf Gouws, David Hauck, Anthony H. Heard, Archbishop Lawrence Henry, Father Theodore M. Hesburgh, C.S.C., Archbishop Denis Hurley, James A. Joseph, Senator Nancy Kassebaum, Hellen Kitchen, Philip Krawitz, Jim Leatt, Helga Liebenberg, George Lindeque, Senator Richard G. Lugar, Penuell Maduna, Trevor Manuel, Thabo Mbeki, Donald McHenry, Tito Mboweni, Rev. Smangaliso Mkhatshwa, E.K. Moorcroft, M.A. Moosa, Nthato Motlana, Sam Motsuenyane, Sipho Mzimela, Beyers Naude, Martin Nasser, J. Daniel O'Flaherty, Gerrit C. Olivier, Millie Olivier, Imam Rashied Omar, PeterJohn Pearson, Alan Paton (deceased), Sister Edith Raidt, Cyril Ramaphosa, Gedeon J. Rossouw, A.M. Rosholt, Kate Savage, Michael Savage, Nick Segal, Walter Sisulu, Frederick van Zyl Slabbert, Eon Smit, Franklin Sonn, Louise Tager, Sampie Terreblanche, Archbishop Buti J. Thagale, Bob Tucker, Archbishop Desmond Tutu, Virginia Van der Vliet, Meg Voorhes, David Welsh, Harold Wolpe, and Denis Worrall.

In developing the factual background for the book, we interviewed, on the record, a large number of people for their roles during the course of events in South Africa. These people included: James Armstrong, Simon Barber, Roger D. Crawford, William D. Donovan, Jr., William Dunning, Christianne Duval, J. Wayne Fredericks, Thomas L. Grooms, George Houser, Sal G. Marzullo (deceased), John O. Mongoven, Herman Nickel, John S. North, Rafael D. Pagan, Jr. (deceased), George Schroll, Leon Sullivan, Helen Suzman, Arthur Swartz, and D. Reid Weedon, Jr.

Our research could not have been conducted without access to the most complete trove of documents pertaining to the Principles program and the activities of the United States signatory companies in complying with the Principles. The documents are housed in the Urban Archives of the Samuel Paley Library of Temple University (International Council for Equality of Opportunity Principles, Acct. 654). We wish to thank the staff of the Urban Archives for their gracious assistance. Another major source of data-espe- 
cially pertaining to the withdrawal of United States companies from South Africa, and to state and local laws against companies doing business in South Africa-was provided by the Investor Responsibility Research Center, Washington, D.C. We are grateful to Ms. Meg Voorhes and other professionals at the IRRC for their cooperation in this effort. Robin Hoen, Executive Director of USSALEP (United States-South Africa Leadership Development Program) was most helpful in providing an overview of the work of nongovernmental organizations in South Africa, including the crucial financial support they received from United States businesses.

As is common in academic research, we were fortunate to draw on the assistance of a number of graduate students of our respective universities at different times from 1995 to 1999 . At the Zicklin School of Business, Baruch College, the City University of New York, a major burden of library research and other support activities was carried out by, among others, Umit Akgoz, B. Elango, Mingwei Guan, Rafael Olano, Rob Panco, and Linda Sama. At the Center for Ethics and Religious Values in Business of the College of Business Administration of the University of Notre Dame, Meghan Dunne served as a research assistant. Deborah Coch and Gillian Pancotti, administrative assistants as Notre Dame and CUNY, respectively, provided much-needed technical and administrative support. We also want to thank our copyeditor, Stephen Scher, and our editor at Kluwer, Ranak Jasani. To all these wonderful people, we are most grateful.

We began this book in earnest in 1995 with the conviction that the whole era of the Sullivan Principles was a remarkable chapter in corporate America's history, and that the story needed to be told in full. After years of involvement in overcoming apartheid in South Africa, we were convinced that the events in that country were a source of important lessons not only for business, but for religious groups and nongovernmental organizations. It is in that spirit that the policies and tactics of key actors are scrutinized and criticized here. Criticisms are offered in the hope that it will help both individuals and corporations to avoid similar mistakes in the future. We must acknowledge, too, that we are far from certain that we ourselves would have done any better had we been making the decisions. And even the best insight and moral judgment may suffer from the "law of unintended consequences." We therefore set forth our thoughts with genuine humility.

Finally, it is our pleasure to dedicate this book to Rev. Leon H. Sullivan, a person of uncommon wisdom and generosity.

Oliver F. Williams, C.S.C.

Notre Dame, Indiana

S. Prakash Sethi

New York, New York 